\title{
Definition of animal breeding goals for sustainable production systems ${ }^{1}$
}

\author{
I. Olesen*,2, A. F. Groen $\dagger$, and B. Gjerde* \\ *AKVAFORSK, Institute of Aquaculture Research AS, N-1432 Ås, Norway and †Animal Breeding and Genetics \\ Group, Department of Animal Sciences, Wageningen Agricultural University, \\ NL-6700 AH Wageningen, The Netherlands
}

\begin{abstract}
What we do is determined by the way we "view" a complex issue and what sample of issues or events we choose to deal with. In this paper, a model based on a communal, cultural, or people-centered worldview, informed by a subjective epistemology and a holistic ontology, is considered. Definitions and interpretations of sustainable agriculture are reviewed. Common elements in published definitions of sustainable agriculture and animal production among those who seek long-term and equitable solutions for food production are resource efficiency, profitability, productivity, environmental soundness, biodiversity, social viability, and ethical aspects. Possible characteristics of future sustainable production systems and further development are presented. The impact of these characteristics on animal breeding goals is reviewed. The need for long-term biologically, ecologically, and sociologi-
\end{abstract}

cally sound breeding goals is emphasized, because animal breeding determined only by short-term market forces leads to unwanted side effects. Hence, a procedure for defining animal breeding goals with ethical priorities and weighing of market and non-market values is suggested. Implementation of non-market as well as market economic trait values in the aggregate genotype, as suggested, may allow for breeding programs that contribute to sustainable production systems. Examples of breeding goals in salmon, cattle, and pigs are given, and the resulting genetic responses are evaluated with respect to economic profit (or costs) and other criteria of sustainability. Important prerequisites for breeding programs for sustainable production are appropriate governmental policies, awareness of our way of thinking, and a more communal worldview informed by a subjective epistemology and a holistic ontology.

Key Words: Animal Breeding, Breeding Objectives, Sustainability, Ethics

(C2000 American Society of Animal Science. All rights reserved.

J. Anim. Sci. 2000. 78:570-582

\section{Introduction}

The Convention on Biological Diversity has three principal objectives: the conservation of the world's biological diversity, sustainable use of its components, and fair and equitable sharing of the benefits to be derived from its use. This convention was signed by 157 countries at the United Nations Conference on Environment and Development in 1992 and came into force as an internationally legally binding law. However, the impact of sustainable use of domestic animal genetic re-

\footnotetext{
${ }^{1}$ Presented at the 49th Annu. Mtg. of the European Association for Animal Production, August 24-27, 1998, Warsaw, Poland. The financial support provided by the Norwegian Research Council (Grant no. 122859/122) is acknowledged and appreciated. The authors gratefully acknowledge the many useful comments and suggestions of $U$. Brenøe, E. Kanis, S. Newman, and T. Steine.

${ }^{2}$ To whom correspondence should be addressed: P.O. Box 5010 (phone: +47 649495 00; fax: +47 649495 02; E-mail: ingrid. olesen@akvaforsk.nlh.no).

Received March 10, 1999.

Accepted September 2, 1999.
}

sources for animal breeding is still rather unclear. The objective of this paper is to discuss defining animal breeding goals for sustainable production systems. As an introduction to this complex area of research and practical management, a general philosophy and major patterns of development that have led to the current situation of agriculture and animal production systems is described. Also, a model of different perspectives, worldviews informed by a specific ontology (the way we see nature) and epistemology (the way we try to learn about nature), is described. The definition of sustainability is discussed, and future trends and consequences for animal breeding goals are given. The general conclusions of the paper are illustrated with examples in cattle, fish, and pig breeding.

\section{General Philosophy}

\section{Evolution of Agriculture and Animal Production Systems}

Bawden (1989) described four phases of evolution in agriculture and animal production systems: pioneering, 
production, productivity, and persistency. When cultivating land, pioneering was an innovative and uncertain activity with a trial-and-error approach using simple technologies. Subsistence agriculture for meeting the immediate needs of the family was the main objective. Mysticism, intuition, and experience helped the pioneers in farming. During the 17 th century, scientists such as Galileo Galilei, Nicolaus Copernikus, Johannes Kepler, and Isaac Newton succeeded in predicting the planets' movements by mathematical formulas. This formed the basis for a mechanistic worldview. René Descartes was one of the important philosophers who agreed that the world was like a machine that we could control. During the middle of the 19th century, Charles Darwin, Louis Pasteur, and Gregor Mendel contributed to the development of the science of nature and agriculture. Production from crops and animals could be increased using scientific principles. From around 1950, mechanization, fertilization, and crop and animal breeding provided the technology to increase production. Economic theories were developed and widely applied. Also, specialized educational and research institutions were established during this phase. In the developed world, fewer and fewer farmers were needed to produce more and more output.

When the problems with overproduction became an obvious paradox, the focus changed from maximization of yield to optimization of return, from gross production to efficiency of production. During this productivity phase, interaction between the production components and inputs and outputs became more important. Agricultural economics and farm management became important disciplines to meet the increasing demands for lower food prices, higher short-term profit, and improved efficiency. Mechanization, chemical inputs, improved genetic material, and advances in pests and disease control contributed to increased productivity of the farms.

Having experienced the negative environmental, social, and ethical side effects of a strong and narrowminded focus on efficiency and productivity, a phase of persistency or sustainability started around 1970 with protection of the environment, natural resources, and animal welfare as main objectives.

The methods of learning and science that were used in the phases of pioneering, production, and productivity have proved to be inadequate to handle the complexity and change associated with contemporary agriculture (Bawden, 1991b). We need other, new ways of learning and dealing with problems in addition to those forms that helped us in the past to be able to develop sustainable production systems with, for example, appropriate animal breeding programs and breeding goals. Bawden $(1989,1991 b)$ argued that there will not be much change in the situation until all the stakeholders are prepared to adopt perspectives on agriculture and nature different from those that currently prevail.

\section{A Model of Perspectives}

Sriskandarajah and Bawden (1994) proposed a model of perspectives, worldviews, that is based on the ideas promoted by Bateson (1972), Checkland (1981), Cotgrove (1982), and Bawden (1989). Two aspects of philosophy that are important for understanding different perspectives are considered here: ontology and epistemology.

The first is our ontology: our belief about what nature is. An extreme ontology of reductionism is a highly fragmented view of nature. Here, the whole is believed to equal the sum of its parts, such that if we know enough about the component parts (e.g., plants, animals, land, water, and air) we can put them all together in the end and understand the whole. Hence, each part can be studied and manipulated in isolation from any other without problems. We may, for example, look at the development of highly industrial and specialized pig and poultry production with long-distant transport of feeds as a result of the reductionistic view of nature. Transportation and huge amounts of nutrients concentrated in a limited area carry with them big environmental problems and, often, reduced resource efficiency. Further negative effects on animal health and welfare, increased drug consumption, and development of resistant bacteria have been experienced in such production systems. An example of reductionistic thinking in animal breeding is the generally applied principle that we can change characteristics of animals independently from other characteristics. The extensive work on QTL and major gene detection we see now is to a large extent based on the belief that there is little or no epistatic interaction and undesirable associations between genes. This is another current expression of this philosophy of reductionism.

The opposite belief is that all plants and animals are dependent on each other and closely integrated with the land, water, and air around them. In this ontology of holism, any change in one part will have a significant impact on the other parts as well as on nature as a whole. For example, organic farming is more based on a holistic view, emphasizes practices that favor the desirable interactions between different elements on the farm, and avoids negative side effects on other natural components. This prevents unbalances and problems that may require short-term solutions with long-term negative side effects. Striving for a balance between the herd size and the feed production on the farm will, for example, restrict the amount of nutrient concentration and leakage, the extent of monocultures, and hence the need for, as an example, pesticide spraying and drug treatments.

The second aspect of philosophy is our epistemological position, or how we try to learn about nature: our ways of analyzing things. At one extreme, we believe we exist in a world of objective reality. We can see the world in a detached, analytical way, and therefore we can find out everything that can ever be known about 


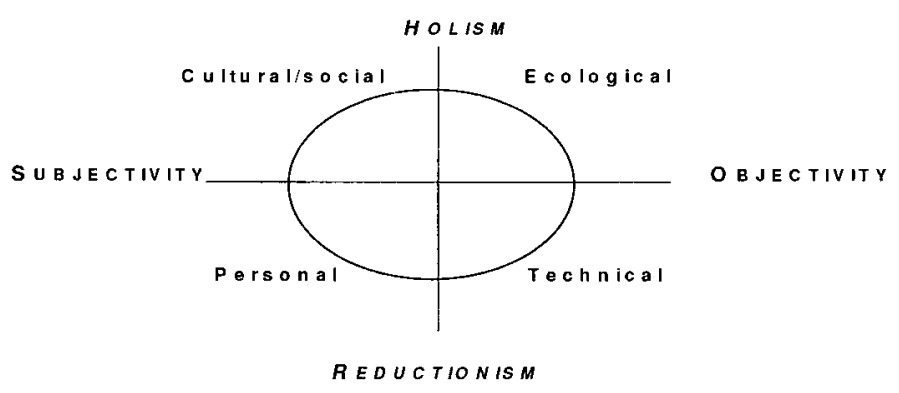

Figure 1. Worldview informed by a holistic or reductionistic ontology and a subjective or objective epistemology (after Sriskandarajah and Bawden, 1994).

nature. Taking this position, we believe that personal values and emotions do not influence how we come to know, and how we make decisions. For example, we may believe that the choice of breeding goal and preference for a certain breed can and should be based on objective calculations and figures only.

The opposite extreme, a subjective view, is that we can only be interpreters; we can only access nature through our minds. Hence, our values, emotions, and interpretations also affect how we come to know and make a single objective truth an illusion. Hence, we might accept that an individual farmer adopts the breeding strategy of a (commercial or cooperative) breeding company only when it gives enough scope for personal preferences when buying breeding stock.

Ontology and epistemology form two dimensions of our worldview, our way of thinking (Sriskandarajah and Bawden, 1994). Four perspectives appear from these two dimensions (Figure 1):

1) a personal, egocentric worldview: a fragmented view of nature, wherein choices made are merely influenced by subjective values, prejudices, and biases;

2) a technical worldview: again a fragmented view of nature, but choices rely on presumed cause-andeffect relationships, objective science, and a mechanistic worldview wherein technological biases dominate;

3) an ecological world view: a holistic view of nature combined with objectivity dominating decision making;

4) a cultural, social worldview: a holistic view of nature and society as a whole, combined with decision making based on subjective values.

Even though we started thinking about wider issues and whole systems in the evolutionary phases of productivity and persistency, we still tended to be objective, and we needed to measure and to quantify. Sriskandarajah and Bawden (1994) argued that ecological thinking alone will not help us out of our difficult situation, because society is already so rich in figures but starved for knowledge. They suggest that we should move more toward the subjective end of the spectrum, the cultural/social perspective of our worldview, to ac- commodate people, their biases, values, attitudes, and aspirations. This is necessary to cooperate as a society, as farming communities, and to start the action to really protect the environment. Vitousek et al. (1997) gave an overview of human domination and its effects on the earth's ecosystems. They also emphasized the importance and challenge of understanding a human-dominated planet, which requires that the human dimensions of global change-the social, economic, cultural, and other drivers of human actions-be included in our analyses. Awareness of this will influence our way of thinking when defining animal breeding goals and is necessary to accommodate sustainable production systems.

Bawden and Zuber-Skeritt (1991) considered a new management style based on process management and management of the processes of human resource development. According to the authors, it permits adaptation to rapid sociological and technological change, empowerment of people, and group consensus about appropriate outcomes. Furthermore, it is appropriate for problems and tasks in an uncertain environment and involves experiential learning (Kolb, 1984), action learning (Revans, 1982), and(or) action research (Bawden, 1989). In this context, Bawden (1989, 1991a) emphasized the importance of reflecting on what we are thinking and what we are doing, while we are thinking and doing, for example, research and developmental work. According to Kitchener (1983), we can discriminate between cognition, meta-cognition (thinking about thinking), and epistemic cognition (concerning what we think about and evaluation of the foundation of thought itself). Bawden and Zuber-Skerritt (1991) emphasize the need for strategies to support "learning to learn", or meta-learning, in research and organizations for a sustainable future.

\section{Definition of Sustainable Production Systems}

The currently popular term "sustainable agriculture" is used to represent everything from organic agriculture to agriculture that maximizes economic yields. A few years ago, there were 800 published definitions of sustainable agriculture, so today there are no doubt many more (Francis, 1997). Sustainability is based on a holistic philosophy, a set of values and principles, but may also involve a specific set of practices. When trying to define animal breeding goals, it is necessary to see and describe the animals as an integrated part of sustainable production systems. Also, we must make clear what we see as a sustainable system.

\section{Resource Sufficiency and Functional Integrity}

Thompson and Nardone (1999) considered two methodological approaches to sustainable livestock production: resource sufficiency and functional integrity. $R e$ source sufficiency presumes that a production practice is sustainable if the resources needed to carry on the 
practice are available or foreseen to be available in the future. The debate over sustainability as resource sufficiency has tended to be a debate with respect to elasticity for resource substitution between optimistic economists (e.g., Simon, 1980; Solow, 1993) and more pessimistic ecologists (e.g., Pimentel et al., 1989; Altieri, 1991). The resource substitution has a dramatic effect on the degree of conservation or on the reduced consumption needed to make a practice sustainable. For example, optimists do not worry much about depleting the sources of fossil fuels, because of the potential for alternative energy provision systems (e.g., solar, wind, and nuclear). Pessimists may, on the contrary, emphasize more the uncertainty of what the future generations will need and the precautionary principle to allow for the same options as the present generations have. Goodland and Daly (1996) argue that depletion rates of nonrenewable resources should equal the rate at which renewable substitutes are developed. Part of the receipts from liquidating oil, for example, should further be invested in research in pursuit of sustainable substitutes. Because of an overly optimistic view that prevails today, this happens to a very little degree and has led to prices that are too low for resources such as oil.

Functional integrity presupposes that the crucial elements of the system are reproduced over time in a manner or at a rate that depends on previous system states. The elements may have both ecological and social limits. The elements to be reproduced may be soil fertility, crops, animal genetic resources, wildlife populations, human populations, or human institutions such as the family or rural communities. Those who emphasize ecological integrity often look upon human practices as threats to functional integrity (e.g., overgrazing). However, human practices can be considered as part of the system. Goodland and Daly (1996) considered environmental sustainability and stressed that it also needs democracy, human resource development, empowerment of women, and much more investment in human capital in addition to economic and social sustainability, although these are not integral parts of the environment. When the social dimensions are included, a complex web of social and psychological prerequisites such as knowledge, capacity, and incentives are necessary before people can perform a desired practice.

Resource sufficiency seems to rely to a large extent on externalizing inputs and outputs. This perspective belongs to the evolutionary phase of productivity and is more informed by an objective epistemology and an ontology of reductionism (technical worldview, Figure 1). Functional integrity concerns more the long-term health of a whole (closed) system. The perspective is more informed by a holistic ontology and a subjective epistemology and will therefore more easily cover the ecological and social perspectives of the diagram by Sriskandarajah and Bawden (1994).

Functional integrity has philosophical priority over the resource sufficiency approach. Thompson and Nar- done (1999) showed how the resource availability framework of mainstream animal science already presupposes functionally integrated subsystems for regenerating key inputs. In other words, resource sufficiency includes judgments that support a conception of functional integrity, but the rhetoric used allows these judgments to remain implicit. For example, the economic benefits for the farmers or the society of improving resource efficiency are assumed to be the main goal, at the expense of, for example, animal welfare or the environment. Also, it requires choices about intergenerational equity. Hence, assumptions about ethical and environmental aspects have been taken implicitly. Castle (1996) argued that this often favors the status quo, even if quality of life is deteriorating due to environmental conditions. Analyzing livestock production in light of functional integrity makes at least some of the assumptions on (relative) importance of aspects (e.g., productivity vs animal welfare) explicit (Thompson and Nardone, 1999). This enhances discussion on these assumptions and facilitates evaluation and agreement on these very fundamental issues. These issues of (relative) importance-productivity, resource efficiency, animal welfare, and so on-are to be made clear before we can define and agree upon animal breeding goals for sustainable production systems.

The Holmenkollen Guidelines (1999) make an example of approaching sustainable aquaculture by functional integrity. These guidelines adopt the following principles:

1) the principle of sustainable development endorsed in the Rio-Declaration of 1992: comprising the interrelation of natural and technological aspects on the one hand, with socioeconomic and value-based considerations on the other;

2) the precautionary principle: in the light of uncertain or inconclusive scientific knowledge, strategies that effectively reduce the possibility of future harm to the environment are called for;

3) the principle of human equity.

\section{Elements of Sustainable Animal Production Systems}

Vavra (1996) explored a philosophical discussion of sustainability and made application to sustainability of animal production systems. He suggested that sustainable systems exist in the overlap of what the current generation wants for itself and future generations and what is biologically and physically possible in the long run. Further, the same quantity of meat, milk, or fiber should be harvested indefinitely from a given land base in a sustainable livestock production system (Heitschmidt et al., 1996; Vavra, 1996). In a review, Torp Donner and Juga (1997) screened different criteria used to describe sustainable livestock production and discussed animal breeding methods that could enhance it. Environmental and economical aspects were also considered here in addition to biodiversity and ethical aspects. The new idea in the term "sustainability" is that environ- 
mental, genetic diversity, ethical, and social aspects should be accounted for in addition to short- and longterm economic value.

We can hope that the diversity of views on sustainable agriculture can lead to more discussion and progress toward improved animal breeding. However, a growing consensus is also desirable for progress on theory development and practical implementation. Fortunately, this consensus can be found around the elements connected to the terms "sustainable agriculture", at least among those who are seeking long-term and equitable solutions to the challenge of food production. Francis and Callaway (1993) summarized these elements of sustainability:

1) resource efficiency: most efficient possible use of nonrenewable resources and, whenever possible, substituting local renewable resources for those imported from outside the farm;

2) profitability: economically profitable in both the short and the long term;

3) productivity: maintaining and enhancing the productivity of all basic resources rather than destroying or degrading them;

4) environmental soundness: minimal negative impact both on the farm and beyond the farm borders;

5) social viability: equitable systems favoring owner/ operator farms, contributing to viable rural economy, infrastructure, and community, supporting and integrating with overall society.

Francis (1997) added to these elements a stronger time and space definition, such that future generations have at least as many options as we have to explore alternative solutions to the food challenge. A more critical look is needed at the globalization of food systems and the energy involved in specialization and distant transport of high-volume food or feedstuffs.

Because sustainability and sustainable agriculture include so many often conflicting elements and desires, it is critical to weigh and give priorities to the different objectives in the term. Otherwise, there is a large risk that the term becomes diluted and loses its meaning. Also, the definition of Vavra (1996) assumes that there is a limited area only where all the different desires overlap, and this needs to be defined by choices and priorities in addition to what is given according to the biological and physical limitations.

\section{Definition of Animal Breeding Goals for Sustainable Systems}

Francis (1997) lists probable characteristics of future agricultural systems. Some of his characteristics and other future development trends we find relevant to animal breeding. These are given together with potential animal breeding strategies in Table 1.

An increase in the world population will emphasize an increase in production and productivity per hectare and higher efficiency per unit of product. Regional increases in human welfare will emphasize the need for producing products of high quality, according to local cultural/social requirements (e.g., meat quality). Product quality is also associated with contaminants from the use of chemical medications and animal-mediated human diseases and with concerns about the production system (e.g., animal welfare and use of biotechnology).

Torp Donner and Juga (1997) reviewed studies suggesting that under current low and intermediate production levels, increased yields and efficiency will be more environmentally sustainable than extensive goals. However, very intense production systems relying on fossil fuels involved in production and transportation carry with them some ecological and economical risks, as also noted by Heitschmidt et al. (1996). This illustrates the need for whole-system analysis when considering sustainability in animal breeding. We need animals that can contribute to optimizing the system. Where land is restricted, we should rather focus on animals that can contribute to increase the farms' production per hectare rather than focusing on increased production per animal. Also, evaluation of various criteria at a level higher than the farm level, at least the regional level, is necessary.

At this point, it is important to consider the "decisionmaker aspect" in animal breeding. Breeding objectives should be concerned with the individual producer's interest, because the producer's primary reason for buying certain breeding stock at a certain price will be based on an assessment of how the animals will contribute to the efficiency of a farm (Harris, 1970). For example, in temperate zones, breeding objectives for intensive milk production have, therefore, been developed for producers or groups of producers rather than for taxpayer-financed national programs; hence, emphasis is put on profit maximization (Pearson, 1986). The socioeconomic (market) attitude of the decision maker influences the perspective (ontology and epistemology) to be considered and is, therefore, crucial in defining the breeding goal. For example, an individual agricultural producer deals with a competitive market, with no individual price setting (Stonier and Hague, 1964), and one cannot expect an individual price-taker not to act according to these (external) prices, even when these prices are misleading from a broader, national perspective (Horring, 1948). A common interest for the society as a whole may not be a sufficient incentive for an individual farmer making breeding decisions (Brascamp et al., 1998). In order to promote breeding goals based on a holistic, long-term perspective, including many of the characteristics of Table 1 , additional governmental policies are required. Legislation (as the environmental legislation in Western Europe), taxes, and user charges may contribute to such incentives for the individual farmer, especially when, for example, the environmental costs are not captured in the marketplace (e.g., Steverink et al., 1994; Goodland and Daly, 1996). Naylor et al. (1998) also stressed the need for incentives through regulation, pollution taxes, or reduc- 
tion of financial subsidies to improve the efficiency and reduce the environmental impacts of shrimp and salmon farming.

An important consideration when deciding on how to approach problems for sustainable systems is also the probability of solving the problem through breeding (Francis, 1997). The fewer the number of genes, the less antagonism between various important traits and the less environmental influence, the greater is the probability of success in breeding. Also, other technical and practical solutions should be considered, because genetic change is a long-term and complex process.

Many of the potential animal breeding strategies mentioned (Table 1) refer to a broader definition of breeding goals, not aiming at higher production levels per animal only, but balancing higher productivity with improved functional traits such as health, fertility, and feed intake capacity.

Sustainable production systems are adjusted to the local, natural, and social conditions. Recognition of differences in cultural/social aspects between regions, but also in natural circumstances, enhances the differentia- tion in breeding goals. Especially when considering the increased privatization of breeding companies and increased worldwide trade of breeding stock, differentiation in breeding goals is important for maintenance of worldwide genetic variability in domestic animals (Hammond, 1993). Not only heterogeneity of production circumstances among regions, countries, or individual farms, but also uncertainty and associated risk about future circumstances, are incentives to differentiate between breeding goals and to maintain different breeding stocks (Smith, 1984).

Genetic improvement is a biological and technological development. The essence of these developments is to improve the efficiency of a production system: saving inputs of production factors per unit product and a change toward the use of cheaper production factors. Saved production factors can either be used in the system where they are saved (and thus expand product output of this system) or can be transferred to another system (e.g., via the market) (Willer, 1967). Different constraints on the production system give rise to alternative uses and, therefore, alternative values of saved

Table 1. Probable characteristics of future agricultural systems and potential animal breeding strategies (after Olesen et al., 1998)

\begin{tabular}{|c|c|}
\hline Characteristic of development & Animal breeding strategy \\
\hline \multicolumn{2}{|c|}{ Technical and ecological aspects } \\
\hline $\begin{array}{l}\text { Increased human food requirement } \\
\text { (larger population and more welfare) }\end{array}$ & $\begin{array}{l}\text { Increase production and productivity; higher efficiency } \\
\text { per unit product; increased intake and utilization of } \\
\text { non-human-food components; improve product quality }\end{array}$ \\
\hline $\begin{array}{l}\text { Higher energy and nutrient costs; } \\
\text { more use of marginal land }\end{array}$ & $\begin{array}{l}\text { Improve utilization of local feeds; reduce costs by } \\
\text { improved health, fertility and other functional traits; } \\
\text { increase intake of (bulky) roughage, and adaptation to } \\
\text { low-energy-input systems }\end{array}$ \\
\hline $\begin{array}{l}\text { Diversification in systems adapted to } \\
\text { specific locations and conditions }\end{array}$ & $\begin{array}{l}\text { Reduce environmental sensitivity of animals } \\
\text { (increased robustness and capacity of adaptation); } \\
\text { diversification of breeding goals }\end{array}$ \\
\hline $\begin{array}{l}\text { Regulations on compounds such as } \\
\text { nitrate and phosphate }\end{array}$ & $\begin{array}{l}\text { Increase biological efficiency in broader terms (not only } \\
\text { energy, but also protein and minerals/elements) }\end{array}$ \\
\hline Reduced use of chemical medications & $\begin{array}{l}\text { Improve genetic disease resistance in general and } \\
\text { tolerance to particular infections and parasites }\end{array}$ \\
\hline Genetic and biotechnology methods & $\begin{array}{l}\text { Introduce more risk-averse strategies after } \\
\text { high-level ethical considerations; } \\
\text { aim at low inbreeding and maintaining genetic diversity }\end{array}$ \\
\hline Concerns about animal welfare & $\begin{array}{l}\text { Improve tolerance to metabolic stress; } \\
\text { improve health, fertility, and longevity; } \\
\text { improve/maintain adaptation to improved management } \\
\text { systems (e.g., floor systems for hens). }\end{array}$ \\
\hline Use of intellectual property rights & Alliances and cooperation; competitive associations \\
\hline $\begin{array}{l}\text { Increased concern about animal-mediated } \\
\text { human diseases }\end{array}$ & $\begin{array}{l}\text { Improve genetic disease resistance in general and } \\
\text { tolerance to particular infections and parasites }\end{array}$ \\
\hline $\begin{array}{l}\text { Privatization of breeding companies, } \\
\text { international trade, increased competition }\end{array}$ & $\begin{array}{l}\text { Alliances and co-operation; competitive associations with } \\
\text { local or market-oriented and diverse breeding goals, } \\
\text { including cultural/social aspects and recognition of } \\
\text { personal preferences }\end{array}$ \\
\hline $\begin{array}{l}\text { Concerns about loss of historical, } \\
\text { cultural breeds and genetic diversity }\end{array}$ & $\begin{array}{l}\text { Develop conservation programs for breeds not under } \\
\text { selection (in situ and ex situ); } \\
\text { maintain or increase effective population sizes of active } \\
\text { breeding populations, and aim for broad breeding goals }\end{array}$ \\
\hline
\end{tabular}


Table 2. Important traits to include in a breeding goal according to the constraints on feed resources and environmental stress of the production system (after Amer et al., 1998)

\begin{tabular}{lcc}
\hline \hline Environmental stress & $\begin{array}{c}\text { Constrained } \\
\text { feed resources }\end{array}$ & $\begin{array}{c}\text { Unconstrained } \\
\text { feed resources }\end{array}$ \\
\hline High & $\begin{array}{c}\text { Adaptability } \\
\text { Feed efficiency }\end{array}$ & $\begin{array}{c}\text { Adaptability } \\
\text { Productivity }\end{array}$ \\
Low & Feed efficiency & Productivity \\
& Product quality & Product quality \\
\hline
\end{tabular}

production factors. Therefore, breeding for high input systems in only the western and industrialized world is not sufficient, nor is it culturally and socially acceptable simply to transfer such high input systems to developing countries together with the breeding stock. Table 2 summarizes important traits that should be emphasized in a breeding goal according to the environmental stress and feed constraints of the production system. When the feed resources are constrained, feed efficiency traits become more important, whereas adaptation and functional traits are more critical for systems with high environmental stress. Again, adaptation to local natural and social conditions is important. With fewer constrained feed resources and low environmental stress, product quality becomes more important.

An additional reason to differentiate between breeding goals and to perform testing programs in specific environments is the genotype $\times$ environmental interaction. When one wants to improve performance in a range of environments simultaneously, general adaptation or robustness (as opposite to environmental sensitivity) of animals may become an important trait for selection (Falconer, 1990). In these respects, Bentsen et al. (1998) presented interesting results on hybrid and purebred tropical fish, tilapia. These results suggest that hybrids may be more sensitive to genotype $\times$ environment interactions affecting the nonadditive component of performance.

Groen et al. (1997) stressed that it is not possible to come up with a "best" methodology in deriving economic values, what is best depends on the traits and production circumstances considered. Moreover, the better method from a theoretical point of view is not necessarily the method that is most practical to implement. Groen et al. (1997) summarized choices to be made in deriving economic values. These choices summarize many of the aspects regarding the influences of sustainability on the definition of animal breeding goals. Actual decisions on these choices should fit the requirements for sustainability in future production systems:

1) modeling approach (objective data simulation or data analysis, or a subjective method);

2) definition of efficiency (economic or biological in terms of energy, protein, or mineral/element);

3) planning term (short-term, or long-term, strategic planning horizon);
4) system level (animal, farm, sector, national, or international level);

5) size of the system (fixed number of animals, fixed input of a production factor, or fixed output of a product);

6) interest of selection (profit maximization, price minimization, or maximization of return on investment).

Incomplete measurement of income and investment, particularly the failure to reflect the use or deterioration of natural capital (e.g., natural resources and ecosystems, in contrast to human-made capital) has been a major obstacle to promoting policies that foster sustainability (Steer and Lutz, 1993; Goodland and Daly, 1996). Animal breeding has so far also focused on cumulative short-term genetic change, because breeding optimization has to a very large extent been based on market economy. Many examples show that animal breeding has led to unwanted side effects that are in conflict with sustainable agriculture. In a review by Rauw et al. (1998), 110 references are presented on undesirable side effects of selection for high production efficiency. Sustainable animal breeding is a long-term and complex process; therefore, we need more focus on longterm biological, ecological, and sociological solutions. In order to approach such a functional integrity of animal breeding, we suggest the following procedure and issues to be answered.

First, the ethical aspects and priorities of top management need to be made clear. How much is, for example, animal welfare emphasized vs higher profit or the consumer demand for improved product quality and lower prices? Some may argue that animal welfare should be valued as much as the consumers are willing to pay for it. Hence, this is an ethical position that has been taken. However, other positions should also be possible. One is that this cannot be valued correctly by the consumers' willingness to pay, and that we put more restrictions on what we can accept of lowered animal welfare.

Second, define the system with respect to limits and structure. The local production conditions and characters of appropriate production system should be described and evaluated with respect to resource efficiency, environmental, economical, and social effects. Which effects may be critical to the reproduction of the system resources, including both ecological and social elements?

Third, define criteria required for or indicators that measure or characterize the above ethical priorities and critical effects of the production system. A farmer's economy and production per hectare are well known and characterized criteria to measure the effects on some aspects of economy and social conditions. Other important criteria may be nutrient leakage, drug consumption, gas production $\left(\mathrm{NH}_{3}, \mathrm{CH}_{4}\right.$, and $\left.\mathrm{CO}_{2}\right)$, resource depletion rate, and behavioral disorders of the animals that may affect resource efficiency, the environment, and morale level. 
Finally, identify animal traits and characters that are important or critical to meet these criteria or objectives. Balance or weigh these traits such that the animals contribute to optimize the whole system constrained on the ethical limits and priorities.

Up to now, weighing of traits has mainly been dependent on economic values and frequency of expression, and the methodology to weigh the traits with respect to resource efficiency and economy is well developed. However, it can be questioned whether this is adequate and allows us to incorporate the ecological, social, and ethical priorities properly. It depends to a high degree on our ability to value social, ecological, and ethical aspects in monetary terms, which is a very big challenge. However, some weighing between different conflicting concerns and interests has to be made. Here, benefits from improved resource efficiency as well as risks of foreseen and unforeseen negative consequences should be taken into account. Some negative consequences may be taken into account via genetic correlations, but others may not and should be accounted for in the breeding objective.

It should be noted that the system is to be optimized according to the ethical priorities (the first point above) and that the objective of animal breeding is to fit animal traits in this system such that it is optimized constrained on the ethical priorities. Some may argue that such ethical priorities and valuation of, for example, ecosystems is either impossible or unwise, because we cannot value such "intangibles" as human life, animal welfare, or long-term ecological benefits. But, in fact, we do so every day. When we set standards for highways, bridges, and the like, we value human life (acknowledged or not), because spending more money on construction would save lives. Others may argue that we should protect the environment and animal welfare for purely moral reasons and that we, therefore, do not need valuations of it. Costanza et al. (1997) valued the world's ecosystem services and natural capital. They argued that moral and economic arguments are not mutually exclusive in such valuations and that both discussions can and should go on in parallel.

Costanza et al. (1997) also discussed the valuation of ecosystem services:

If ecosystem services were actually paid for, in terms of their value contribution to the global economy, the global price system would be very different from what it is today. The price of commodities using ecosystem services directly or indirectly would be much greater. The structure of factor payments, including wages, interest rates and profits would change drastically.

Changes in quality and quantity of animal traits have value insofar as they either change the benefits associated with human activities or change the costs of those activities. These changes in benefits and costs either have an impact on human welfare through established markets or through nonmarket activities, as for ecosystem services considered by Costanza et al. (1997). This implies that traits affecting product value (i.e., product quality resulting from product price relationships originating from the market's supply and demand changes) should be taken into account. However, we should in addition include important nonmarket values of animal traits (e.g., ethical values of improved animal welfare through less suffering from diseases or stress and a higher quality of life). There may also be other values of natural capital and ecosystem services improved by changes in traits contributing to, for example, slower depletion of fossil energy and reduced degradation of the atmosphere, that are not easily traceable through well-functioning markets. Such values accrue directly to humans without passing through the money economy at all (Costanza et al., 1997). Naylor et al. (1998) also shared their concerns about the ecological and social costs of fish farming that producers and consumers are unaware of, and do not pay for, because they are not reflected in either local or international prices for aquaculture inputs or outputs.

Hence, the traits' values in the aggregate genotype may be split into nonmarket values (NV) and market values in the money economy (ME). Correspondingly, we will obtain a genetic gain of nonmarket value in addition to a market genetic gain. This gives the following breeding goal (considering 2 traits $\mathrm{Y}$ ): $\mathrm{H}=\left[\mathrm{NV}_{1} \times\right.$ $\left.\mathrm{Y}_{1}+\mathrm{ME}_{1} \times \mathrm{Y}_{1}\right]+\left[\mathrm{NV}_{2} \times \mathrm{Y}_{2}+\mathrm{ME}_{2} \times \mathrm{Y}_{2}\right]$. The value of the nonmarket gain is $\mathrm{NV}_{1} \times \Delta \mathrm{G}_{1}+\mathrm{NV}_{2} \times \Delta \mathrm{G}_{2}$, where $\Delta \mathrm{G}_{\mathrm{i}}$ is the genetic change in trait $\mathrm{i}$, and likewise for the market gain. The total genetic gain is a sum of the nonmarket genetic gain and market genetic gain. As we see, a trait may have both nonmarket and market value. Reduced disease frequency increases both the ethical value through improved animal welfare and through reduced economic costs of treatments and reduced yield. However, a trait may as well have only non-market value or only market economic value. The resulting nonmarket and market genetic gains give us an opportunity to evaluate the breeding programs in a more holistic perspective, in which social, cultural (including subjective values), ecological, and economic objectives and effects can be taken into account.

In order to demonstrate the effects of different ethical priorities and perspectives taken when defining animal breeding goals, three simplified examples are presented.

\section{Example in Salmon}

The example in salmon shows effects of various ethical priorities of market economic vs nonmarket environmental and animal welfare aspects. For this example, three traits only are considered: age at slaughter, survival in the sea period, and feed consumption. For the reasons of simplicity, traits affecting market product value (e.g., product quality) were omitted, although these may be important. For parameters see Table 3; only favorable genetic correlations are assumed between different traits. Information included in the se- 
Table 3. Salmon example. Mean, phenotypic standard deviation $\left(\sigma_{\mathrm{p}}\right)$, heritability $\left(\mathrm{h}^{2}\right.$, on diagonal), phenotypic ( $\mathrm{r}_{\mathrm{p}}$, above diagonal), genetic correlations $\left(\mathrm{r}_{\mathrm{g}}\right.$, below diagonal), and index information ( $\mathrm{i}=$ individual; $\mathrm{fs}=$ full-sibs; $\mathrm{hs}=$ half-sibs)

\begin{tabular}{|c|c|c|c|c|c|c|c|}
\hline \multirow[b]{2}{*}{ Trait } & \multirow[b]{2}{*}{ Mean } & \multirow[b]{2}{*}{$\sigma_{\mathrm{p}}$} & \multicolumn{3}{|c|}{$\mathbf{h}^{2}, \mathrm{r}_{\mathrm{p}}, \mathrm{r}_{\mathrm{g}}$} & \multicolumn{2}{|c|}{ Information } \\
\hline & & & 1. & 2. & 3. & Alt. 1 & Alt. 2,3 \\
\hline 1. Age at slaughter, $d$ & 500 & 100 & .25 & -.1 & .3 & $\begin{array}{c}\mathrm{i} \\
+30 \mathrm{fs} \\
+30 \mathrm{hs}\end{array}$ & $\begin{aligned} & \mathrm{i} \\
+ & 30 \mathrm{fs} \\
+ & 30 \mathrm{hs}\end{aligned}$ \\
\hline 2. Survival sea period, $\%$ & 85 & 36 & -.1 & .05 & 0 & - & $\begin{array}{r}50 \mathrm{fs} \\
+50 \mathrm{hs}\end{array}$ \\
\hline $\begin{array}{l}\text { 3. Feed consumption, } \\
\mathrm{kg} \text { feed } \cdot 100 / \mathrm{kg} \text { meat }\end{array}$ & 110 & 22 & .3 & 0 & .20 & - & - \\
\hline
\end{tabular}

lection index and market and nonmarket values used in the aggregate genotype for three alternatives are in Tables 3 and 4 . For the first alternative, age at slaughter and feed consumption have non-zero market economic value. The latter is, however, not considered in the information index due to difficulties in recording feed consumed in fish. This may reflect a priority of market value and short-term profit only. The other alternatives reflect increasing concerns about negative effects on survival. The economic values of alternative 2 have mainly been based on market values and economic benefits of improving the traits (Olsen et al., 1994), corresponding fairly well to the values assumed for these traits in the Norwegian Salmon Breeding Pro-

Table 4. Salmon example. Relative market economic values (ME, NOK/unit), nonmarket values (NV, NOK/ unit) per alternative; predicted selection response per generation (selection intensity $=1$ ) per trait $(\Delta G)$ and for the total aggregate genotype $(\Delta \mathrm{H})$; predicted selection response assuming market and nonmarket values as in alternative $3: \Delta \mathrm{H}_{1}=$ market economic response, $\Delta \mathrm{H}_{2}=$ nonmarket response, $\Delta \mathrm{H}_{3}=$ total response

\begin{tabular}{lccc}
\hline \hline & \multicolumn{3}{c}{ Alternative } \\
\cline { 2 - 4 } Trait & 1 & 2 & 3 \\
\hline Age at slaughter, d & & & \\
ME & -.010 & -.006 & -.006 \\
$\mathrm{NV}$ & 0 & 0 & .003 \\
$\Delta \mathrm{G}$ & -32.20 & -26.18 & -24.32 \\
Survival, \% & & & \\
$\mathrm{ME}$ & 0 & .14 & .14 \\
$\mathrm{NV}$ & 0 & 0 & .07 \\
$\Delta \mathrm{G}$ & .52 & 3.04 & 3.36 \\
Feed consumption, & & & \\
$\mathrm{kg}$ feed·100/kg meat & & & \\
$\mathrm{ME}$ & -.18 & -.10 & -.10 \\
$\mathrm{NV}$ & 0 & 0 & -.05 \\
$\Delta \mathrm{G}$ & -5.07 & -3.86 & -3.54 \\
Selection response, NOK & & & \\
$\Delta \mathrm{H}$ & 1.23 & .97 & 1.31 \\
$\Delta \mathrm{H}_{1}$ & .77 & .97 & .97 \\
$\Delta \mathrm{H}_{2}$ & .08 & .16 & .34 \\
$\Delta \mathrm{H}_{3}$ & .85 & 1.13 & 1.31 \\
\hline
\end{tabular}

gram. For the third alternative, we emphasize the nonmarket value of survival and feed consumption beyond what will pay economically on a short-term basis, and this may reflect a stronger ethical priority of nonmarket values made here.

Predicted total selection response in alternatives 1 , 2 , and 3 is $1.23, .97$, and $1.31 \mathrm{NOK}$, respectively (Table 4). However, assuming the market and nonmarket values in alternative 3 to be true ones, we see that the genetic gain in alternative 1 is overestimated, and both the market and nonmarket responses are lower than for alternatives 2 and 3. Although there are favorable correlations between age at slaughter on one side and survival or feed consumption on the other, this example shows a reduction in the total genetic gain $\left(\Delta \mathrm{H}_{3}\right)$ when emphasizing some traits beyond their true (market + nonmarket) value and when ignoring nonmarket values of other traits.

\section{Example in Cattle}

For this example, again nonmarket values of traits are applied in addition to market economic values, and nonmarket values may here also include the long-term economic (or strategic) values, but now unfavorable genetic correlations between traits also are assumed. Alternative cattle breeding schemes are compared assuming the phenotypic and genetic parameters and index information given in Table 5, and market and nonmarket values in Table 6. Alternative 1 aims at increasing production capacity only and may reflect a resource sufficiency paradigm without considering, for example, longterm ecological and ethical effects. Increased short-term economic profit from improved milk and beef yields is the main goal in alternative 1 . Alternative 2 is based on a broader breeding goal, where improvement in traits other than milk yield is also emphasized. However, the economic values have mainly been based on the increased profit from improving the traits. The trait values assumed here are close to the values applied for these traits in the Norwegian Red breeding program (Steine, 1998). For alternative 3 , other, more long-term economic values from improving the traits rather than short-term profit have been emphasized in addition to the ethical value of lower frequency of diseases. 
Table 5. Cattle example. Mean, phenotypic standard deviation $\left(\sigma_{\mathrm{p}}\right)$, heritability $\left(\mathrm{h}^{2}\right.$, on diagonal), phenotypic ( $\mathrm{r}_{\mathrm{p}}$, above diagonal), genetic correlations $\left(\mathrm{r}_{\mathrm{g}}\right.$, below diagonal), and index information (number of progeny)

\begin{tabular}{|c|c|c|c|c|c|c|c|c|}
\hline \multirow[b]{2}{*}{ Trait } & \multirow[b]{2}{*}{ Mean } & \multirow[b]{2}{*}{$\sigma_{\mathrm{p}}$} & \multicolumn{4}{|c|}{$\mathbf{h}^{2}, \mathbf{r}_{\mathrm{p}}, \mathrm{r}_{\mathrm{g}}$} & \multicolumn{2}{|c|}{ Information } \\
\hline & & & 1. & 2. & 3. & 4. & Alt. 1 & Alt. 2,3 \\
\hline 1. Milk, kg & 6,300 & 894.0 & .20 & .20 & .10 & -.10 & 280 & 280 \\
\hline 2. Mastitis, \% & 17 & 38.5 & .31 & .03 & .09 & -.01 & - & 300 \\
\hline 3. Beef, NOK & 10,000 & 328.0 & .16 & .09 & .15 & -.21 & 250 & 250 \\
\hline 4. Fertility, \% & 67 & 45.8 & -.10 & -.01 & -.21 & .05 & - & 300 \\
\hline
\end{tabular}

Resulting selection responses at a selection intensity of unity are given in Table 6 . Due to unfavorable correlations between milk yield and diseases and the increased number of traits in the breeding goal, the response in milk yield drops dramatically in alternatives 2 and 3 compared to alternative 1 . However, the overall genetic gain in monetary terms is higher in alternative 2 , because of the high economic values assumed for the other traits. A slight decrease in overall market economic gain can be seen for alternative 3 compared to alternative 2 , due to lowered selection pressure on milk yield and beef production. This may reflect an economic cost we would have to pay today for appreciating values and interests other than the short-term economic ones expressed

Table 6. Cattle example. Relative market economic values (ME, NOK/unit), nonmarket values (NV, NOK/ unit) per alternative; predicted selection response per generation (selection intensity $=1$ ) per trait $(\Delta G)$ and for the total aggregate genotype $(\Delta \mathrm{H})$; predicted selection response assuming market and nonmarket values as in alternative $3: \Delta \mathrm{H}_{1}=$ market economic response, $\Delta \mathrm{H}_{2}=$ nonmarket response, $\Delta \mathrm{H}_{3}=$ total response

\begin{tabular}{lccc}
\hline \hline & \multicolumn{3}{c}{ Alternative } \\
\cline { 2 - 4 } Trait & 1 & 2 & 3 \\
\hline Milk, kg & & & \\
ME & 1.00 & 1.00 & 1.00 \\
NV & 0 & 0 & 0 \\
$\Delta \mathrm{G}$ & 345 & 216 & 167 \\
Mastitis, \% & & & \\
ME & 0 & -60 & -60 \\
NV & 0 & 0 & -15 \\
$\Delta \mathrm{G}$ & 1.9 & -1.9 & -2.6 \\
Beef, NOK & & & \\
ME & 1.81 & 1.81 & 1.81 \\
NV & 0 & 0 & 0 \\
$\Delta \mathrm{G}$ & 72.6 & 47.3 & 37.3 \\
Fertility, \% & & & \\
ME & 0 & 26.0 & 26.0 \\
NV & 0 & 0 & 6.5 \\
$\Delta$ & -1.8 & 2.7 & 3.4 \\
Selection response, NOK & & & \\
$\Delta \mathrm{H}$ & 476.4 & 485.8 & 540.0 \\
$\Delta \mathrm{H}_{1}$ & 307.0 & 485.8 & 478.9 \\
$\Delta \mathrm{H}_{2}$ & -12.4 & 46.1 & 61.1 \\
$\Delta \mathrm{H}_{3}$ & 294.7 & 531.9 & 540.0 \\
\hline & & &
\end{tabular}

through the market economy. However, if the trait values are chosen for strategic, long-term reasons, such genetic changes turn out to be more beneficial in the longer term. Hence, the costs may be paid back and the genetic changes will be beneficial in the future. If the nonmarket values, for example, were estimates based on the value of a reduced rate of antibiotic-resistant bacteria due to lower mastitis frequency, we should be able to show a genetic gain for this.

\section{Example in Pigs}

The third example, pig breeding, is different from the first two, but it also reflects different perspectives taken and hence ethical priorities of nonmarket values. Effects of applying national self-support of feeds and nutrients, and thereby reducing risk of nutrient leakage, on nonmarket values of the traits and market, nonmarket, and total selection response are studied. For the derivation of economic values the model by De Vries (1989) was used. Some basic situation parameters were updated to accommodate the situation in the Dutch pig industry in 1992 and 1993 (Table 7). The updated model was used to give the market economic values (Table 8). Also, a "sustainable" situation of self-supply of feed in The Netherlands, implying a balanced situation for the availability of feed and the use of manure on arable land, was studied. A simplified model was used to calculate the nitrogen intake per slaughter pig (including intake of animals used for reproduction) to be $8.35 \mathrm{~kg}$. The total $\mathrm{N}$ output per slaughter pig is $5.67 \mathrm{~kg}$. Total availability of arable land in The Netherlands for growing grain for

Table 7. Pig example. Updated price and performance parameters for the model by De Vries (1989)

\begin{tabular}{lc}
\hline \hline Parameter & Value \\
\hline Additional days nonpregnant because of reinsemination, d & 7 \\
Salvage value of disposed sow, Dfl/kg & 2.00 \\
Market price replacement gilt, Dfl/kg & 430 \\
Feed price for pigs from birth to weaning, Dfl/kg & .68 \\
Feed price for pigs during growing period, Dfl/kg & .43 \\
Litter size born, total & 11.8 \\
Litter size born alive & 11.0 \\
Litter size weaned & 9.5 \\
Cullings, sow/yr, \% & 48.3 \\
Farrowings, sow/yr & 2.17 \\
\hline
\end{tabular}


the pig industry was calculated to be 285,100 ha, with a total output of $53,620,000 \mathrm{~kg}$ of $\mathrm{N}$ per year. This means that aiming at a national balance between $\mathrm{N}$ intake by (slaughter) pigs and feed (grain) $\mathrm{N}$ produced in The Netherlands on a yearly basis, a maximum of only $(53,620,000 / 8.35) 6.42$ million slaughter pigs can be produced. For comparison, almost 24 million slaughter pigs were produced in The Netherlands in 1996. When aiming at a national balance between $\mathrm{N}$ supply by the manure of (slaughter) pigs and $\mathrm{N}$ production by the feed grain yearly (53,620,000/5.67), 9.45 million slaughter pigs can be produced. These figures are far below the current numbers of pigs produced in The Netherlands. For simplicity, the probable increase in the price of domestic pork, due to the decrease in pork production, is not taken into account. This might, however, alter the relative market values for the sustainable situation compared to the basic situation. As a result of discounting increased costs of manure management to feed costs, improvement of the traits that increase feed efficiency (turnover of $\mathrm{N}$ ) becomes more important. Nonmarket values of traits were assigned based on the change in values of genetic improvement due to the implementation of the restriction of self-supply (Table 8); the changes in trait values in the sustainable situation are due to initial ethical priorities (resulting in, for example, imposed national self-supply of feeds).

Index calculations were performed to illustrate the effect of nonmarket values on genetic superiority from selection. A simplified aggregate genotype with four traits (litter size born alive, growth, feed intake of growing pigs, and estimated percentage of lean meat) was considered. Nucleus breeding in sows of a dam line (combined selection for reproduction and production traits) is assumed. Index selection is based on recordings for first-parity sows: litter size and performance, 3 full sibs and 20 paternal half-sibs, growth rate, feed intake, and lean meat percentage of 25 paternal half-sibs tested as growing pigs. In addition to this full index, a reduced index without records for feed intake of the 25 paternal half-sibs was studied. The genetic parameters assumed are given in Table 8.

Imposing a national feed self-supply for the pig industry in The Netherlands would tremendously decrease population size. For the remaining industry, manure management would lead to an increased feed price. The effects of this increase in feed price on trait values and selection response by index selection are rather limited (Tables 8 and 9). The largest effects of a more sustainable perspective here can be found for nonmarket selection responses, also because the nonmarket trait values were assumed different. However, the simple example used shows the major influence on selection responses from including feed intake in the recording scheme of tested fattening pigs. Testing growing pigs for feed intake would drastically reduce an unfavorable trend in (increased) feed intake and (reduced) nonmarket selection response with only little loss in genetic response for growth rate.

\section{General Discussion and Conclusions}

As Bawden (1991b) pointed out, what we do is determined by the way we see such a complex issue as sustainable production, and what sample of issues or events we choose to deal with. Hence, seeing and considering animal breeding in view of its impact on genetic diversity, environment, and society is a prerequisite for being able to find and carry out significant actions toward animal breeding for sustainable production systems. Thompson and Nardone (1999) also state that, if ethical norms of animal welfare and bioethics are to be reflected in future research, animal science must become even more pluri- and interdisciplinary and welcome philosophy and ethical debate. They concluded that animal sciences have a significant capacity to address sustainable livestock production as a problem of resource efficiency. Furthermore, the current organization of agricultural research institutes makes it entirely unclear who will do research on functional integrity and integrate it with traditional research on the production process (Thompson, 1995). Hence, animal science should develop more in-depth approaches to the issue of sustainability in strict cooperation with other disciplines (Thompson and Nardone, 1999). This is in agreement with the conclusion of the European Association of Animal Production working group on economic values in dairy cattle breeding (Groen et al., 1997).

Table 8. Pig example. Market economic (ME) and nonmarket (NV) values (Dfl/ slaughter pigs); phenotypic standard deviation $\left(\sigma_{\mathrm{p}}\right)$, heritability $\left(\mathrm{h}^{2}\right.$, on diagonal), phenotypic $\left(\mathrm{r}_{\mathrm{p}}\right.$, above diagonal), and genetic correlations $\left(\mathrm{r}_{\mathrm{g}}\right.$, below diagonal)

\begin{tabular}{llcccccr}
\hline \hline & & & \multicolumn{4}{c}{$\mathrm{h}^{2}, \mathrm{r}_{\mathrm{p}}, \mathrm{r}_{\mathrm{g}}$} \\
\cline { 5 - 7 } Trait & $\mathrm{ME}$ & $\mathrm{NV}$ & $\sigma_{\mathrm{p}}$ & 1. & 2. & 3. & 4. \\
\hline $\begin{array}{l}\text { 1. Litter size born alive, } \\
\text { pigs/litter }\end{array}$ & 8.01 & .75 & 2.85 & .08 & .10 & -.10 & 0 \\
$\begin{array}{l}\text { 2. Growth rate of growing } \\
\text { pigs, g/d }\end{array}$ & .212 & .031 & 88 & 0 & .25 & .85 & -.15 \\
$\begin{array}{l}\text { 3. Feed intake of growing } \\
\text { pigs, g/d }\end{array}$ & -.051 & -.11 & 200 & 0 & .65 & .25 & -.35 \\
\begin{tabular}{l} 
4. Lean meat, \% \\
\hline
\end{tabular} & 2.89 & 0 & 2.5 & 0 & -.10 & -.30 & .45 \\
\hline
\end{tabular}


Table 9. Selection responses for breeding goal traits and overall from index selection for the basic situation and a sustainable situation (intensity of selection $\mathrm{i}=1$ )

\begin{tabular}{|c|c|c|c|c|}
\hline \multirow[b]{3}{*}{ Trait } & \multicolumn{4}{|c|}{ Selection response } \\
\hline & \multicolumn{2}{|c|}{ Basic situation } & \multicolumn{2}{|c|}{ Sustainable situation } \\
\hline & $\begin{array}{c}\text { Reduced } \\
\text { index }^{\mathrm{a}}\end{array}$ & $\begin{array}{l}\text { Full } \\
\text { index }\end{array}$ & $\begin{array}{c}\text { Reduced } \\
\text { index }^{\mathrm{a}}\end{array}$ & $\begin{array}{l}\text { Full } \\
\text { index }\end{array}$ \\
\hline Litter size born alive, pigs/litter & .256 & .262 & .261 & .267 \\
\hline Growth rate of growing pigs, g/d & 7.925 & 7.383 & 8.050 & 7.432 \\
\hline Feed intake of growing pigs, g/d & 4.323 & .917 & 4.677 & .900 \\
\hline Lean meat, $\%$ & .364 & .354 & .347 & .336 \\
\hline Market economic response, Dfl & 4.564 & 4.642 & 4.562 & 4.639 \\
\hline Nonmarket response, Dfl & 0 & 0 & -0.069 & .332 \\
\hline Total response, Dfl & 4.564 & 4.642 & 4.493 & 4.971 \\
\hline Accuracy of selection & .417 & .424 & .415 & .424 \\
\hline
\end{tabular}

${ }^{\mathrm{a}} \mathrm{Feed}$ intake is not recorded in the 25 paternal half-sibs tested for production performance.

From the definition of sustainability given here, it is obvious that the unilateral market economy is not sufficient for determining the direction of agricultural and aquacultural development. During the last century, it has had considerable impact on the development of agriculture, and it has shown to be unable to take resource efficiency and environmental and social aspects into account properly (Daly, 1993). Hence, short-term profit is incompatible with the long-term objective needed for sustainable agriculture and aquaculture as defined here. Costanza et al. (1997) also emphasized that we must begin to give the natural capital stock (in contrast to human-made capital) that produces ecosystem services adequate weight in the decision-making process. Otherwise, current and continued future human welfare may drastically suffer. Because ecosystem services are largely outside the market and uncertain, they are too often ignored or undervalued, leading to the error of designing breeding schemes whose social or ecological costs may outweigh their benefits, as also expressed in more general terms by Costanza et al. (1997). Application of the suggested procedure for defining breeding goals that require ethical priorities and include nonmarket values in the aggregate genotype may, however, allow for breeding programs that contribute to sustainable production systems.

Democratic control of the market economy is a tool to obtain a resource-efficient, long-term economic, productive, environmentally sound, and socially viable agriculture and aquaculture. Knowledge and information about the consequences of alternative food production strategies on short-term and long-term economy, environment, and rural development (both market and nonmarket selection responses) are essential for being able to make correct choices and decisions. In order to get a real democratic steering, public information and teaching in biology and food production is needed. Jasanoff et al. (1997) also discussed how to reach out to the public about scientific issues affecting their lives. They concluded that rather than unidirectional information flow from experts to the public, two-way communication with the public seems more promising. This also requires that animal scientists and stakeholders take a different perspective that is more informed by a holistic ontology and subjective epistemology and recognize the paradigm of functional integrity.

\section{Implications}

Animal breeding for sustainable production systems requires that environmental and social concerns are taken into account, and, hence, ethical priority of values other than short-term and market economic are necessary. A procedure for defining breeding goals that requires ethical priorities and inclusion of appropriate nonmarket and market trait values in the aggregate genotype may allow animal breeding to contribute to sustainable production systems. Emphasizing values other than short-term economic profit in the breeding goal may lower the short-term market value and increase the nonmarket (e.g., ethical or long-term) economic value of genetic gain, or it may require alternative testing schemes with recording of other traits. Other prerequisites for breeding programs for sustainable production include appropriate governmental policies, awareness of our way of thinking, and a more communal worldview informed by a subjective epistemology and a holistic ontology.

\section{Literature Cited}

Altieri, M. 1991. An agroecological analysis of the environmental degradation resulting from the structure of agriculture. In: P. B. Thompson and B. A. Stout (Ed.) Beyond the Large Farm: Ethics and Research Goals for Agriculture. pp 125-135. Westview Press, Boulder, CO.

Amer, P. R., N. Mpofu, and O. Bondoc. 1998. Definition of breeding objectives for sustainable production systems. 6th World Congr. Genet. Appl. Livest. Prod. 28:97-104.

Bateson, G. 1972. Steps to an Ecology of Mind. Ballentine, New York.

Bawden, R. J. 1989. Towards action researching systems. In: O. ZuberSkeritt (Ed.) Action Research for Change and Development. pp 20-51. Centre for the Advancement of Learning and Teaching, Griffith University, Brisbane, Australia. 
Bawden, R. J. 1991a. Reflections on the action of reflections in action: Of cars, helicopters and satellites. In: O. Zuber-Skerritt (Ed.) Action Learning for Improved Performance. Key contributions to the First World Congress on Action Research and Process Management. pp 86-90. ÆBIS Publishing, Brisbane, Australia.

Bawden, R, J. 1991b. Systems thinking and practice in agriculture. J. Dairy Sci. 74:2362-2373.

Bawden, R. J., and O. Zuber-Skerritt. 1991. Learning, process management and change. In: O. Zuber-Skerritt (Ed.) Action Learning for Improved Performance. Key Contributions to the First World Congress on Action Research and Process Management. pp 77-85. ÆBIS Publishing, Brisbane, Australia.

Bentsen, H. B., A. E. Eknath, M. S. Palada-de Vera, J. C. Danting, H. L. Bolivar, R. A. Reyes, E. E. Dionisio, F. M. Longalong, A. V. Circa, M. M. Tayamen, and B. Gjerde. 1998. Genetic improvement of farmed tilapias: Growth performance in a complete diallel cross experiment with eight strains of Oreochromis niloticus. Aquaculture 160:145-173.

Brascamp, E. W., A. F. Groen, I.J.M. De Boer, and H. Udo. 1998. The effect of environmental factors on breeding goals. 6th World Congr. Genet. Appl. Livest. Prod. 27:129-136.

Castle, E. N. 1996. A pluralistic, pragmatic and evolutionary approach to natural resource management. In: A. Light and E. Katz (Ed.) Environmental Pragmatism. pp 231-250. Routledge, New York.

Checkland, P. B. 1981. Systems Thinking: System Practise. John Wiley, New York.

Costanza, R., R. D’Arge, R. De Groot, S. Farber, M. Grasso, B. Hannon, K. Limburg, S. Naeem, R. V. O'Neill, J. Paruelo, R. G. Raskin, P. Sutton, and M. van den Belt. 1997. The value of the world's ecosystem services and natural capital. Nature (Lond.) 387:253-260.

Cotgrove, S. 1982. Catastrophe or Cornucopia? Humanity and Nature: Ecology, Science and Society. Pluto Press, London.

Daly, H. E. 1993. The perils of free trade. Sci. Am. (Nov.):24-29.

De Vries, A. G. 1989. A model to estimate economic values of traits in pig breeding. Livest. Prod. Sci. 21:49-66.

Falconer, D. S. 1990. Selection in different environments: Effects on environmental sensitivity (reaction norm) and on mean performance. Genet. Res. Camb. 56:57-70.

Francis, C. A. 1997. Sustainability, problems, challenges and visions. Paper presented at the 23rd Nordic-Baltic Postgraduate Course in Plant Breeding, Jõgeva, Estonia.

Francis, C. A., and M. B. Callaway. 1993. Crop improvement for future farming systems. In: B. Callaway and C. A. Francis (Ed.) Crop Improvement for Sustainable Agriculture. pp 1-18. University of Nebraska Press, Lincoln.

Goodland, R., and H. Daly. 1996. Environmental sustainability: Universal and non-negotiable. Ecol. Appl. 6:1002-1017.

Groen, A. F., T. Steine, J. Colleau, J. Pedersen, J. Pribyl, and N. Reinsch. 1997. Economic values in dairy cattle breeding, with special reference to functional traits. Report of an EAAP-working group. Livest. Prod. Sci. 49:1-21.

Hammond, K. 1993. The status, state and conservation of animal genetic resources. FAO, Rome (Mimeo).

Harris, D. L. 1970. Breeding for efficiency in livestock production: Defining the economic objectives. J. Anim. Sci. 30:860-865.

Heitschmidt, R. K., R. E. Short, and E. E. Grings. 1996. Ecosystems, sustainability, and animal agriculture. J. Anim. Sci. 74:1395-1405.

Holmenkollen Guidelines. 1999. Holmenkollen guidelines for sustainable aquaculture 1997. In: N. Svennevig, H. Reinertsen, and M. New (Ed.) Sustainable Aquaculture. Proc. of the Second International Symposium on Sustainable Aquaculture: Food for the future? November 2-5, 1997, Oslo, Norway. pp 343-347. AA. Balkema, Rotterdam/Brookfield.

Horring, J. 1948. Methode van kostprijsberekening. Ten Kate, Emmen. Jasanoff, S., R. Colwell, M. S. Dresselhaus, R. D. Goldman, M.R.C. Greenwood, A. S. Huang, W. Lester, S. A. Levin, M. C. Linn, J.
Lubschenko, M. J. Novacek, A. C. Roosevelt, J. E. Taylor, and N. Wexler. 1997. Conversations with the community: AAAS at the millennium. Science (Wash DC) 278:2066-2067.

Kitchener, J. 1983. Cognition, meta-cognition and epistemic cognition: A three level model of cognitive processing. Hum. Dev. 26:222-232.

Kolb, D. 1984. Experiential Learning-Experience as the Source of Learning and Development. Prentice-Hall, Englewood Cliffs, NJ.

Naylor, R. L., R. J. Goldburg, H. Mooney, M. Beveridge, J. Clay, C. Folke, N. Kautsky, J. Lubschenko, J. Primavera, and M. Williams. 1998. Nature's subsidies to shrimp and salmon farming. Science (Wash DC) 282:883-884.

Olesen, I., G. Klemetsdal, U. T. Brenøe, and O. Vangen. 1998. Will sustainability affect animal breeding? 6th World Congr. Genet. Appl. Livest. Prod. 27:157-160.

Olsen, B. A, M. Rye, and B. Gjerde. 1994. Økonomisk verdi for aktuelle produksjonsegenskaper hos laks. Nor. Fiskeoppd. 11A94:157-160.

Pearson, R. E. 1986. Ecnomic evaluation of breeding objectives in dairy cattle: Intensive specialized milk production in temperate zones. 3rd World Congr. Genet. Appl. Livest. Prod. 9:11-17.

Pimentel, D., T. W. Culliney, I. W. Buttler, D. J. Reinemann, and K. B. Beckman. 1989. Low-input sustainable agriculture using ecological management practices. In: M. G. Paoletti, B. R. Stinner, and G. G. Lorenzoni (Ed.) Agriculture, Ecosystems and Environment: Special Issue. Proc. Int. Symposium on Agricultural Ecology and Environment, April 5-7, 1988, Padova, Italy. Agric. Ecosyst. Environ. 27:3-24.

Rauw, W. M., E. Kanis, E. N. Noordhuizen-Stassen, and F. J. Grommers. 1998. Undesirable side effects of selection for high production efficiency in farm animals. A review. Livest. Prod. Sci. 56:15-33.

Revans, R. W. 1982. The Origins and Growth of Action Learning. Chartwell-Bratt, Bromley \& Lund.

Simon, J. 1980. Resources, population and environment: An oversupply of false bad news. Science (Wash DC) 208:431-437.

Smith, C. 1984. Genetic aspects of conservation in farm livestock. Livest. Prod. Sci. 11:37-48.

Solow, R. M. 1993. Sustainability: An economist's perspective. In: R. Dorfman and N. S. Dorfman (Ed.), Economics of the Environment: Selected Readings. pp 179-187. W. W. Norton and Co., New York.

Sriskandarajah, N., and R. Bawden. 1994. Farming as a human activity: An alternative world view. Paper presented at a seminar on Achieving Results by Cooperation Within Environmental Protection and Agriculture, Kookola, Finland.

Steer, A., and E. Lutz. 1993. Measuring environmentally sustainable development. Finance Dev. 30(4):20-23.

Steine, T. 1998. Realised effect of selection for mastitis resistance. Proc. 1998 Interbull Meeting, Rotorua, New Zealand Bull. No. 17. pp 115-117.

Steverink, M.H.A., A. F. Groen, and P.B.M. Berentsen. 1994. The influence of environmental policies for dairy farms on dairy cattle breeding goals. Livest. Prod. Sci. 40:251-261.

Stonier, A. W., and D. C. Hague. 1964. A Textbook of Economic Theory. Longmans and Green, London.

Thompson, P. B. 1995. The Spirit of the Soil and Environmental Ethics. Routledge, New York.

Thompson, P. B., and A. Nardone. 1999. Sustainable livestock production: Methodological and ethical challenges. Livest. Prod. Sci. 61:111-119.

Torp Donner, H., and J. Juga. 1997. Sustainability-a challenge to animal breeding. Agric. Food Sci. Finl. 6:229-239.

Vavra, M. 1996. Sustainability of animal production systems: An ecological perspective. J. Anim. Sci. 74:1418-1423.

Vitousek, P. M., H. A. Mooney, J. Lubschenko, and J. M. Melillo. 1997. Human domination of earth's ecosystems. Science (Wash DC) 277:494-499.

Willer, H. 1967. Technische Fortschritte und Landwirtschaft. Verlag Paul Parey, Hamburg, Germany. 